\title{
Mathematical Modeling of Thin-Layer Drying Kinetics of Piper aduncum L. Leaves
}

\author{
Wellytton Darci Quequeto ${ }^{1}$, Valdiney Cambuy Siqueira², Geraldo Acácio Mabasso ${ }^{2}$, Eder Pedroza Isquierdo ${ }^{3}$, \\ Rafael Araujo Leite ${ }^{2}$, Lucas Rodrigues Ferraz ${ }^{2}$, Renata Henrique Hoscher ${ }^{2}$, Vanderleia Schoeninger ${ }^{2}$, \\ Rodrigo Aparecido Jordan ${ }^{2}$, André Luis Duarte Goneli ${ }^{2} \&$ Elton Aparecido Siqueira Martins ${ }^{2}$ \\ ${ }^{1}$ Instituto Federal de Educação, Ciência e Tecnologia Goiano, Campus Rio Verde, Goiás, Brazil \\ ${ }^{2}$ Faculdade de Ciências Agrárias, Universidade Federal da Grande Dourados, Dourados, Mato Grosso do Sul, \\ Brazil \\ ${ }^{3}$ Universidade do Estado de Mato Grosso, Campus de Cáceres, Mato Grosso, Brazil \\ Correspondence: Wellytton Darci Quequeto, Instituto Federal de Educação, Ciência e Tecnologia Goiano, \\ Campus Rio Verde, Goiás, Brazil. E-mail: wellytton_quequeto@hotmail.com
}

Received: March 16, 2019

doi:10.5539/jas.v11n8p225
Accepted: April 27, $2019 \quad$ Online Published: June 15, 2019

URL: https://doi.org/10.5539/jas.v11n8p225

\begin{abstract}
As well as most agricultural products, some medicinal plants need to go through a drying process to ensure quality maintenance, however each product behaves differently. Therefore, the present study aimed to evaluate the drying kinetics of spiked pepper (Piper aduncum L.) leaves and determine their thermodynamic properties at different drying temperatures in laboratory scale. Leaves with initial moisture content of $78 \%$ w.b. (wet basis) were subjected to drying at temperatures of $40,50,60$ and $70{ }^{\circ} \mathrm{C}$ and air speed of $0.85 \mathrm{~m} \mathrm{~s}^{-1}$ in an experimental fixed bed dryer. The drying kinetics of the leaves was described by statistical fitting of mathematical models and determination of effective diffusion coefficient and activation energy. Enthalpy, entropy and Gibbs free energy were also evaluated for all drying conditions. It was concluded that, among the models evaluated, only Midilli and Valcam can be used to represent the drying of Piper aduncum leaves; the first for the two highest temperatures $\left(60\right.$ and $\left.70{ }^{\circ} \mathrm{C}\right)$ and the second for 40 and $50{ }^{\circ} \mathrm{C}$. The activation energy was approximately $55.64 \mathrm{~kJ}$ $\mathrm{mol}^{-1}$, and the effective diffusion coefficient increase with the elevation of temperature. The same occurs with the values of Gibbs free energy, whereas the specific enthalpy and entropy decrease.
\end{abstract}

Keywords: spiked pepper, AIC and BIC, activation energy, medicinal plant

\section{Introduction}

The species Piper aduncum L., popularly known as spiked pepper, has organic compounds with antifungal action which act on the elimination of skin and hair diseases (Monzote, Scull, Cos, \& Setzer, 2017). It has a stimulating action for digestion, liver and healing (Maia et al., 1998). Its essential oil can be used to combat fungi of the species Colletotrichum musae, Trichophyton mentagrophytes, Trichophyton tonsurans and Magnaporthe grisea (Guerrini et al., 2009), besides the action against the protozoa Leishmania amazonenses and Trypanosoma cruzi (Bastos \& Albuquerque, 2004; Villamizar, Cardoso, Andrade, Teixeira, \& Soares, 2017), which caused infectious diseases in humans.

Drying is one of the main processes conducted to ensure the maintenance of quality of most agricultural products. There are several advantages in using drying, such as product preservation, stability of aromatic components at room temperature for long periods of time, protection against enzymatic degradation and oxidation, mass reduction, energy saving for not requiring refrigeration, and it also contributes with more adequate conditions of storage, making the product available during any period of the year.

Since it is a complex process, which involves heat and mass transfers (Yilbas, Hussain, \& Dincer, 2003; Delgado \& Lima, 2016; Haghi \& Amanifard, 2008), several studies have been conducted in the attempt to describe drying, especially at laboratory scale, by fitting mathematical models, using statistical parameters. Modeling allows describing the drying kinetics (Al-Ali \& Parthasarathy, 2019) and therefore predicting the behavior of the product during the process, as well as optimizing the operation parameters in the dryer project (Nadi, 2016). 
According to Silva, Siqueira, Martins, Miranda and Melo (2017), along the drying process it is interesting to not only describe the drying kinetics, but also to monitor the thermodynamic properties. They provide important information on the properties of water and on the energy required in the process, such as enthalpy and entropy, which characterize variations existing in the water-product system (Corrêa, Oliveira, Botelho, Goneli, \& Carvalho, 2010).

Given the above, the present study aimed to describe the drying kinetics of Piper aduncum leaves, selecting the mathematical model that best represents the phenomenon, and determine the diffusion coefficient and thermodynamic properties of the product.

\section{Material and Methods}

\subsection{Research Conduction}

Piper aduncum L. leaves were collected at the Federal University of Grande Dourados (UFGD), in the garden of the Faculty of Agrarian Sciences (FCA).

The collection was carried out randomly on consecutive days, at the same time, provided that there was no dew on leaf surface to avoid a possible interference in the drying curve of the leaves. After collection, the leaves were sent to the laboratory and properly selected, so that those which had damaged parts were eliminated.

\subsection{Drying Kinetics of the Leaves}

The leaves were distributed on four screen-bottom trays and placed in an experimental dryer. The dryer is equipped with a system which accurately controls the drying air flow and temperature.

Initial and equilibrium moisture contents of the samples were determined by the gravimetric method in the oven, at $103 \pm 1{ }^{\circ} \mathrm{C}$, for $24 \mathrm{~h}$, in four replicates (ASABE, 2010). The drying temperatures adopted were 40, 50, 60 and $70{ }^{\circ} \mathrm{C}$, under controlled conditions. Drying air speed was monitored using a spinning-cup anemometer and maintained at around $0.85 \mathrm{~m} \mathrm{~s}^{-1}$.

The drying of the leaves began with moisture content of approximately $78 \%$ w.b. (wet basis) and ended when the leaves reached equilibrium moisture content. However, a final moisture content of $9.0 \%$ w.b., which is the one adopted commercially, was adopted to plot the data.

The moisture ratio of Piper aduncum leaves was determined through the following expression (Wang et al., 2018):

$$
\mathrm{RX}=\frac{\mathrm{X}-\mathrm{X}_{\mathrm{e}}}{\mathrm{X}_{\mathrm{i}}-\mathrm{X}_{\mathrm{e}}}
$$

where, RX: moisture ratio of the product, dimensionless; $X$ : moisture content of the product (decimal d.b.); $\mathrm{X}_{\mathrm{i}}$ : initial moisture content of the product (decimal d.b.); and $\mathrm{X}_{\mathrm{e}}$ : equilibrium moisture content of the product (decimal d.b.).

\subsection{Mathematical Modeling and Diffusion Coefficient}

Periodic weighing at preestablished periods of time allowed obtaining the data required to fit the mathematical model (Table 1) through nonlinear regression. 
Table 1. Mathematical models used to predict the thin-layer drying of agricultural products

\begin{tabular}{lll}
\hline Model & Model designation & \\
\hline Modified Henderson and Pabis (Karathanos, 1999) & $\mathrm{RX}=\mathrm{a} \cdot \exp (-\mathrm{kt})+\mathrm{b} \cdot \exp \left(-\mathrm{k}_{0} \mathrm{t}\right)+\mathrm{c} \cdot \exp \left(-\mathrm{k}_{1} \mathrm{t}\right)$ & $(2)$ \\
Verma (Verma et al., 1985) & $\mathrm{RX}=-\mathrm{a} \cdot \exp (-\mathrm{kt})+(1-\mathrm{a}) \cdot \exp \left(-\mathrm{k}_{1} \mathrm{t}\right)$ & $(3)$ \\
Two-term exponential (Sharaf-Eldee et al., 1980) & $\mathrm{RX}=\mathrm{a} \cdot \exp (-\mathrm{kt})+(1-\mathrm{a}) \cdot \exp (-\mathrm{kat})$ & $(4)$ \\
Two terms (Henderson, 1974) & $\mathrm{RX}=\mathrm{a} \cdot \exp \left(-\mathrm{k}_{0} \mathrm{t}\right)+\mathrm{b} \cdot \exp \left(-\mathrm{k}_{1} \mathrm{t}\right)$ & $(5)$ \\
Midilli (Midilli, 2002) & $\mathrm{RX}=\mathrm{a} \cdot \exp \left(-\mathrm{kt}^{\mathrm{n}}\right)+\mathrm{bt}$ & $(6)$ \\
Logarithmic (Yagcioglu et al., 1999) & $\mathrm{RX}=\mathrm{a} \cdot \exp (-\mathrm{kt})+\mathrm{c}$ & $(7)$ \\
Henderson and Pabis (Henderson \& Pabis, 1961) & $\mathrm{RX}=\mathrm{a} \cdot \exp (-\mathrm{kt})$ & $(8)$ \\
Page (Page, 1949) & $\mathrm{RX}=\exp \left(-\mathrm{kt} \mathrm{t}^{\mathrm{n}}\right)$ & $(9)$ \\
Newton (Lewis, 1921) & $\mathrm{RX}=\exp (-\mathrm{kt})$ & $(10)$ \\
Wang and Singh (Wang \& Singh, 1978) & $\mathrm{RX}=1+\mathrm{at}+\mathrm{bt}^{2}$ & $(12)$ \\
Valcam (Siqueira et al., 2013) & $\mathrm{RX}=\mathrm{a}+\mathrm{bt}+\mathrm{ct} \mathrm{t}^{1.5} \cdot \mathrm{dt}^{2}$ & $(13)$ \\
Thompson (Thompson et al., 1968) & $\mathrm{RX}=\exp \frac{-\mathrm{a}-\left(\mathrm{a}^{2}+4 \mathrm{bt}\right)^{0.5}}{2 \mathrm{~b}}$ & \\
Approximation of diffusion (Kassem, 1998) & $\mathrm{RX}=\mathrm{a} \cdot \exp (-\mathrm{kt})+(1-\mathrm{a}) \cdot \exp (-\mathrm{kbt})$ & $(14)$ \\
\hline
\end{tabular}

Note. t: Drying time, $\mathrm{h} ; \mathrm{k}, \mathrm{k}_{0}, \mathrm{k}_{1}$ : Drying parameters, $\mathrm{h}^{-1}$; and $\mathrm{a}, \mathrm{b}, \mathrm{c}, \mathrm{d}, \mathrm{n}$ : Coefficients of the models.

The effective diffusion coefficients for the several drying temperatures were determined using Equation 15, based on the liquid diffusion theory, which considers an infinite flat slab.

$$
\mathrm{RX}=\frac{\mathrm{X}-\mathrm{X}_{\mathrm{e}}}{\mathrm{X}_{\mathrm{i}}-\mathrm{X}_{\mathrm{e}}}=\frac{8}{\pi^{2}} \sum_{\mathrm{n}=0}^{\infty} \frac{1}{(2 \mathrm{n}+1)^{2}} \exp -\left[\frac{(2 \mathrm{n}+1) \pi^{2} \mathrm{D}_{\mathrm{ef}}}{4}\left(\frac{\mathrm{t}}{4 \mathrm{~L}}\right)^{2}\right]
$$

where, $D_{\text {ef: }}$ effective diffusion coefficient, $\mathrm{m}^{2} \mathrm{~s}^{-1} ; \mathrm{t}$ : drying time, $\mathrm{h}$; L: thickness of the product, $\mathrm{m}$; and $\mathrm{n}$ : number of terms of the model.

Thickness (L) was measured using a digital micrometer, with resolution of $0.001 \mathrm{~mm}$. To obtain the average thickness of Piper aduncum leaves, 50 leaves were randomly chosen among the set of leaves which were going to be dried, and readings were taken at six preestablished points, three on each side of the midrib (Silva et al., 2017).

The behavior of the effective diffusion coefficient according to the different temperatures applied during the drying process was evaluated with Arrhenius equation, described in Equation 16.

$$
\mathrm{D}_{\mathrm{ef}}=\mathrm{D}_{0} \exp \left(\frac{\mathrm{E}_{\mathrm{a}}}{\mathrm{RT}_{\mathrm{a}}}\right)
$$

where, $\mathrm{D}_{0}$ : pre-exponential factor; $\mathrm{R}$ : universal gas constant, $8.314 \mathrm{~kJ} \mathrm{kmol}^{-1} \mathrm{~K}^{-1} ; \mathrm{T}_{\mathrm{a}}$ : temperature, $\mathrm{K}$; and $\mathrm{E}_{\mathrm{a}}$ : activation energy, $\mathrm{kJ} \mathrm{mol}^{-1}$.

\subsection{Thermodynamic Properties}

The thermodynamic properties, specific enthalpy, specific entropy and Gibbs free energy, as a function of the drying kinetics of Piper aduncum leaves, were determined according to the method described by Jideani and Mpotokwana (2009), using Equations 17, 18 and 19.

$$
\begin{aligned}
& \mathrm{h}=\mathrm{E}_{\mathrm{a}}-\mathrm{RT}_{\mathrm{a}} \\
& \mathrm{s}=\mathrm{R}\left(\ln \mathrm{D}_{0}-\ln \frac{\mathrm{k}_{\mathrm{B}}}{\mathrm{h}_{\mathrm{p}}}-\ln \mathrm{T}_{\mathrm{a}}\right) \\
& \mathrm{G}=\mathrm{h}-\mathrm{T}_{\mathrm{a}} \mathrm{s}
\end{aligned}
$$

where, h: enthalpy, $\mathrm{J}_{\mathrm{mol}^{-1}}$; s: entropy, $\mathrm{J} \mathrm{mol}^{-1}$; G: Gibbs free energy, $\mathrm{J}^{\text {mol }}{ }^{-1} ; \mathrm{k}_{\mathrm{B}}$ : Boltzmann's constant, $1.38 \mathrm{x}$ $10^{-23} \mathrm{~J} \mathrm{~K}^{-1}$; and $\mathrm{h}_{\mathrm{p}}$ : Planck's constant, $6.626 \times 10^{-34} \mathrm{~J} \mathrm{~s}^{-1}$.

\subsection{Statistical Parameters}

The experimental data of the thin-layer drying kinetics of Piper aduncum leaves were analyzed and subjected to nonlinear regression analysis, through the Gauss-Newton method, using the program Statistica 7.0. 
The degree of fit of each model was analyzed considering the magnitudes of the coefficient of determination $\left(\mathrm{R}^{2}\right)$, mean relative error $(\mathrm{P})$ and standard deviation of the estimate (SE). The models which obtained the best fits were subjected to the Akaike (AIC) and Bayesian (BIC) Information Criteria. The values of mean relative error (P), standard deviation of the estimate (SE), AIC and BIC were calculated according to the following equations:

$$
\begin{gathered}
\mathrm{P}=\frac{100}{\mathrm{n}} \sum_{\mathrm{i}=1}^{\mathrm{n}}\left(\frac{|\mathrm{Y}-\hat{\mathrm{Y}}|}{\mathrm{Y}}\right) \\
\mathrm{SE}=\sqrt{\frac{\sum_{\mathrm{i}=1}^{\mathrm{n}}{ }^{2}}{\mathrm{GLR}}} \\
\mathrm{AIC}=-2 \operatorname{logL}+2 \mathrm{p} \\
\mathrm{BIC}=-2 \log \mathrm{L}+\mathrm{p} \cdot \ln (\mathrm{N}-\mathrm{r})
\end{gathered}
$$

where, Y: valued observed experimentally; $\hat{Y}$ : value estimated by the model; $n$ : number of experimental observations; DF: degrees of freedom of the model; $\mathrm{p}$ : number of parameters of the model; N: total number of observations; r: rank of X matrix (incidence matrix of fixed effects); and L: maximum likelihood.

\section{Results and Discussion}

In Table 2, from the mean relative error (P) it can be observed that only Midilli (6) and Valcam (12) models showed values lower than $10 \%$ for all drying temperatures studied. According to Mohapatra and Rao (2005), the mean relative error is a parameter that can be used for recommending or not a model, and it reflects the deviation of the observed values from the curve estimated by the model (Kashaninejad, Mortazavi, Safekordi \& Tabil, 2007). Thus, for the models mentioned, the deviation can be considered as acceptable.

\begin{tabular}{|c|c|c|c|c|c|c|c|c|c|c|c|c|}
\hline \multirow{2}{*}{ Models } & \multicolumn{3}{|c|}{$40^{\circ} \mathrm{C}$} & \multicolumn{3}{|c|}{$50^{\circ} \mathrm{C}$} & \multicolumn{3}{|c|}{$60^{\circ} \mathrm{C}$} & \multicolumn{3}{|c|}{$70^{\circ} \mathrm{C}$} \\
\hline & $\mathrm{P}$ & $\mathrm{SE}$ & $\mathrm{R}^{2}$ & $\mathrm{P}$ & SE & $\mathrm{R}^{2}$ & $\mathrm{P}$ & SE & $\mathrm{R}^{2}$ & $\bar{P}$ & $\mathrm{SE}$ & $\mathrm{R}^{2}$ \\
\hline (2) & 2.42 & 0.009 & 0.99 & 10.39 & 0.029 & 0.99 & 25.48 & 0.080 & 0.94 & 3.91 & 0.016 & 0.99 \\
\hline (3) & 114.5 & 0.191 & 0.60 & 12.10 & 0.033 & 0.60 & 10.83 & 0.028 & 0.99 & 7.50 & 0.025 & 0.99 \\
\hline (4) & 31.12 & 0.049 & 0.97 & 12.92 & 0.033 & 0.97 & 14.15 & 0.039 & 0.98 & 34.14 & 0.112 & 0.86 \\
\hline (5) & 11.50 & 0.021 & 0.99 & 5.33 & 0.050 & 0.99 & 11.84 & 0.035 & 0.98 & 7.06 & 0.024 & 0.99 \\
\hline (6) & 5.40 & 0.013 & 0.99 & 5.77 & 0.017 & 0.99 & 5.07 & 0.015 & 0.99 & 2.76 & 0.012 & 0.99 \\
\hline (7) & 12.11 & 0.021 & 0.99 & 6.23 & 0.016 & 0.99 & 10.00 & 0.026 & 0.99 & 6.84 & 0.038 & 0.98 \\
\hline (8) & 28.97 & 0.047 & 0.97 & 20.69 & 0.048 & 0.97 & 25.48 & 0.071 & 0.94 & 28.98 & 0.096 & 0.90 \\
\hline (9) & 15.02 & 0.031 & 0.98 & 12.01 & 0.034 & 0.98 & 7.56 & 0.026 & 0.99 & 6.66 & 0.028 & 0.99 \\
\hline (10) & 12.11 & 0.021 & 0.99 & 22.19 & 0.049 & 0.99 & 30.30 & 0.081 & 0.92 & 34.14 & 0.109 & 0.86 \\
\hline (11) & 6.87 & 0.019 & 0.99 & 4.67 & 0.019 & 0.99 & 10.81 & 0.027 & 0.99 & 7.15 & 0.022 & 0.99 \\
\hline (12) & 2.60 & 0.010 & 0.99 & 4.34 & 0.015 & 0.99 & 5.16 & 0.015 & 0.99 & 4.51 & 0.017 & 0.99 \\
\hline (13) & 31.12 & 0.049 & 0.97 & 22.19 & 0.050 & 0.97 & 30.30 & 0.083 & 0.92 & 34.14 & 0.112 & 0.86 \\
\hline (14) & 10.47 & 0.021 & 0.99 & 12.10 & 0.033 & 0.99 & 12.71 & 0.036 & 0.98 & 7.63 & 0.026 & 0.99 \\
\hline
\end{tabular}

Table 2. Coefficients of determination $\left(\mathrm{R}^{2}\right.$, decimal), mean relative error $(\mathrm{P}, \%)$ and standard deviation of the estimate (SE, decimal) for the eleven models analyzed, during the drying of Piper aduncum leaves under different conditions of temperature $\left({ }^{\circ} \mathrm{C}\right)$

According to the values of standard deviation of the estimate (SE), as in the case of the mean relative error, Midilli (6) and Valcam (12) models were also those with the best results. According to Draper and Smith (1998), the standard deviation of the estimate indicates the capacity of a model to accurately describe a certain physical process and the lower its magnitude, the better the quality of fit of the model to the experimental data.

Also in Table 2, it can be observed that only Midilli (6), Logarithmic (7), Page (9), Wang and Singh (11), Valcam (12) and Approximation of diffusion (14) models showed coefficients of determination $\left(\mathrm{R}^{2}\right)$ above $98 \%$ for all drying temperatures. Thus, according to Kashaninejad et al. (2007), they can satisfactorily represent the drying phenomenon.

Among the models which stood out considering the previously calculated statistical parameters (Midilli and Valcam), Akaike (AIC) and Schwarz's Bayesian (BIC) Information Criteria (Table 3) were also considered as 
additional parameters to select the best model to satisfactorily represent the experimental data. According to Wolfinger (1993), the lower the values of AIC and BIC, the better the fit of the mathematical model, and BIC is considered as the strictest criterion.

Table 3. Akaike Information Criterion (AIC) and Schwarz's Bayesian Information Criterion (BIC) for the models which best fitted to the drying data of Piper aduncum leaves under different conditions of temperature

\begin{tabular}{|c|c|c|c|c|c|c|c|c|}
\hline \multirow{2}{*}{ Models } & \multicolumn{2}{|c|}{$40^{\circ} \mathrm{C}$} & \multicolumn{2}{|c|}{$50^{\circ} \mathrm{C}$} & \multicolumn{2}{|c|}{$60^{\circ} \mathrm{C}$} & \multicolumn{2}{|c|}{$70^{\circ} \mathrm{C}$} \\
\hline & AIC & $\mathrm{BIC}$ & AIC & BIC & AIC & $\mathrm{BIC}$ & AIC & $\mathrm{BIC}$ \\
\hline (6) & -166.722 & -161.509 & -146.835 & -139.998 & -109.476 & -104.253 & -118.374 & -113.152 \\
\hline (12) & -258.386 & -249.697 & -153.819 & -146.983 & -108.666 & -103.444 & -103.915 & -98.693 \\
\hline
\end{tabular}

Considering the lowest values of AIC and BIC (Table 3), the Midilli (6) model showed the best fit to the experimental data for the two highest temperatures $\left(60\right.$ and $\left.70{ }^{\circ} \mathrm{C}\right)$, whereas the Valcam model showed the best fit for the temperatures of 40 and $50^{\circ} \mathrm{C}$. Thus, these two models were selected to represent the drying kinetics of Piper aduncum leaves. Gomes, Resende, Sousa, Oliveira and Araújo Neto (2018), Ferreira Junior, Resende, Oliveira and Costa (2018) and Xavier et al. (2019), also obtained satisfactorily results using AIC and BIC to select mathematical models in works in the field of post-harvest.

Figure 1 shows the thin-layer drying curves $\left(40,50,60\right.$ and $\left.70{ }^{\circ} \mathrm{C}\right)$ of Piper aduncum leaves, represented by the Midilli and Valcam models. There was a high correspondence between experimental and estimated values, and a satisfactory fit of Midilli and Valcam models under the respective conditions studied. Several researchers have recommended these models to predict the drying process of agricultural products: Ziziphus joazeiro leaves (Sousa et al., 2015); Ocimum basilicum L. leaves (Reis, Devilla, Ascheri, Servulo, \& Souza, 2012); Mentha x piperita leaves (Gasparin, Christ, \& Coelho, 2017); Phaseolus vulgaris L. grains (Quequeto, Siqueira, Ferranti, Schoeninger, \& Leite, 2017); Jatropha curcas L. fruits (Siqueira, Resende \& Chaves, 2013); Bauhinia forficata leaves (Silva et al., 2017) and Coffea arabica grains (Siqueira et al., 2017).

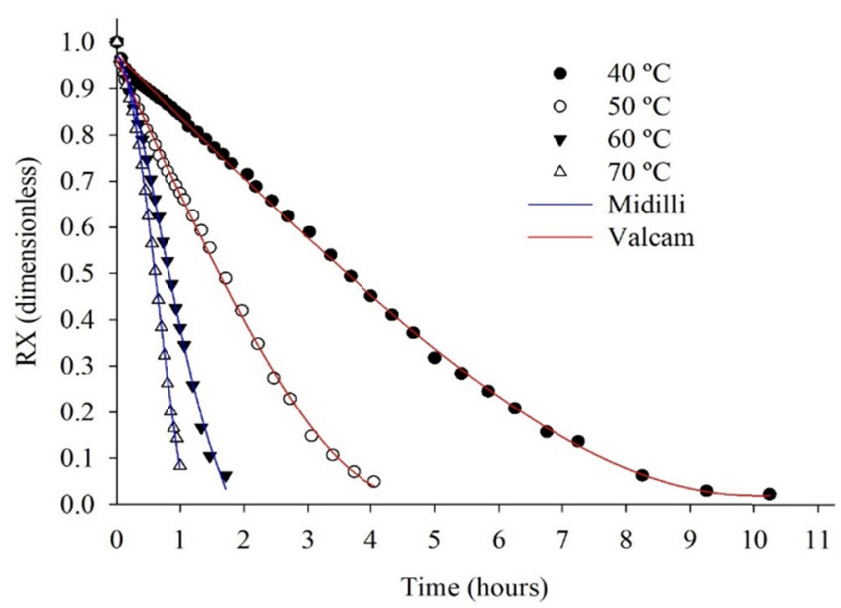

Figure 1. Values of moisture content ratio obtained experimentally and estimated by the Midilli and Valcam models for the thin-layer drying of Piper aduncum leaves under different conditions of temperature

Table 4 presents the parameters of the Midilli and Valcam models fitted to the experimental data of thin-layer drying of Piper aduncum leaves, for the different conditions of air temperature used. There was no specific behavior for the values of the parameters of both models with the increase in drying air temperature. Except for the parameter " $b$ " of the Valcam model, all had high degree of significance by t-test. 
Table 4. Estimated values of the parameters of Midilli and Valcam models for different conditions of air temperature in the thin-layer drying of Piper aduncum leaves

\begin{tabular}{llllll}
\hline \multirow{2}{*}{ Parameters } & \multicolumn{2}{c}{ Midilli } & & \multicolumn{2}{c}{ Valcam } \\
\cline { 2 - 3 } \cline { 5 - 6 } & $40{ }^{\circ} \mathrm{C}$ & $50{ }^{\circ} \mathrm{C}$ & & $60{ }^{\circ} \mathrm{C}$ & $70^{\circ} \mathrm{C}$ \\
\hline $\mathrm{a}$ & $0.9460^{* *}$ & $0.9646^{* *}$ & & $0.9746^{* *}$ & $0.9746^{* *}$ \\
$\mathrm{~b}$ & $-0.0077^{* *}$ & $-0.0572^{* *}$ & & $0.1926^{\mathrm{ns}}$ & $0.4592^{\mathrm{ns}}$ \\
$\mathrm{k}$ & $0.1006^{* *}$ & $0.2892^{* *}$ & & - & - \\
$\mathrm{n}$ & $1.3887^{* *}$ & $1.1099^{* *}$ & & - & - \\
$\mathrm{c}$ & - & - & & $-1.4900^{* *}$ & $-2.4263^{* *}$ \\
$\mathrm{~d}$ & - & - & & $0.7061^{* *}$ & $1.0571^{* *}$ \\
\hline
\end{tabular}

Note. ${ }^{* *}$ Significant at 0.05 significance level; ${ }^{\text {ns }}$ Not significant by t-test.

It can be seen in Figure 2 that, during the drying process, the effective diffusion coefficient (D) ranged from 0.4655 to $2.9395 \times 10^{-12}\left(\mathrm{~m}^{2} \mathrm{~s}^{-1}\right)$ and that its values increased with the increment in drying air temperature. Similar behavior has been observed by Silva et al. (2017); Martins, Lage, Goneli, Cesar Filho, and Lopes (2015) and Goneli, Vieira, Vilhasanti, and Gonçalves (2014), studying the drying kinetics of medicinal plants. These authors highlight that, when the temperature is increased, the level of vibration in water molecules increases, thus reducing its viscosity, leading to alterations in water diffusion through the capillaries of the agricultural products, which along with the more intense vibration of water molecules contribute to a faster diffusion.

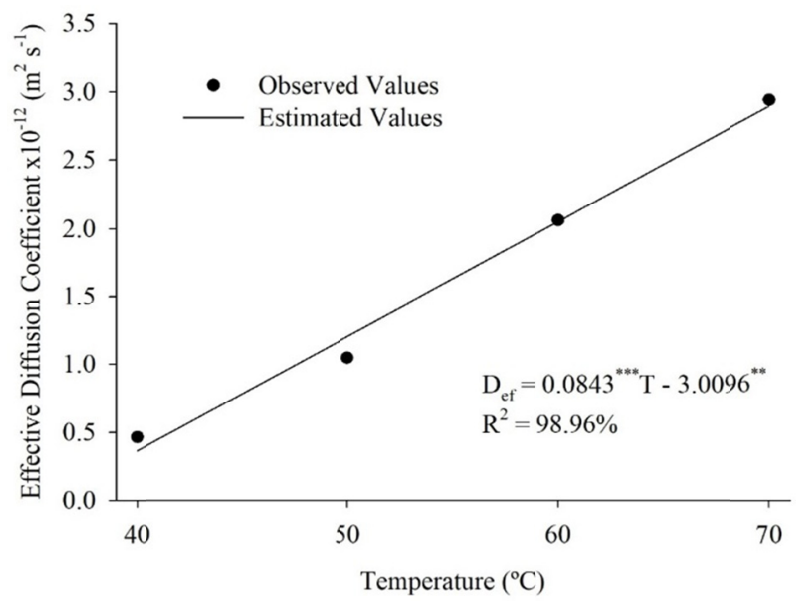

Figure 2. Average values of the effective diffusion coefficient $\left(\mathrm{D}_{\mathrm{ef}}\right)\left(\mathrm{m}^{2} \mathrm{~s}^{-1}\right)$ obtained for drying of Piper aduncum, considering average leaf area of $0.00807 \mathrm{~m}^{2}$ under different conditions of temperature

Note. ${ }^{* * *}$ Significant at $0.01 ;{ }^{* *}$ Significant at 0.05 by t-test.

Goneli et al. (2014), studying the drying kinetics of Schinus terebinthifolius leaves for a temperature range from 40 to $70^{\circ} \mathrm{C}$, observed that the effective diffusion coefficient varied from $0.1476 \times 10^{-11}$ to $1.5811 \times 10^{-11} \mathrm{~m}^{2} \mathrm{~s}^{-1}$. Martins et al. (2015), in studies with Serjania marginata leaves, found values from $0.6630 \times 10^{-11}$ to $12.0712 \times$ $10^{-11} \mathrm{~m}^{2} \mathrm{~s}^{-1}$, also for the same temperature range. In both cases, the variation range of the effective diffusion coefficient is higher than that of the present study. This behavior may be related to the morphological characteristic of the leaves, and the thickness of Piper aduncum leaves was on average $0.1687 \mathrm{~mm}$, whereas the thicknesses of Schinus terebinthifolius and Serjania marginata were 0.3631 and $0.5922 \mathrm{~mm}$, respectively. Silva et al. (2017) found that leaf thickness is a factor to be considered in the analysis of the effective diffusivity of leaves during drying. However, it is important to emphasize that the chemical composition should also be taken into consideration.

Figure 3 presents the values of $\operatorname{Ln}(\mathrm{D})$ as a function of the inverse of the absolute temperature obtained for Piper aduncum leaves. The decreasing linearity demonstrates the uniform variation of the drying rate within the studied temperature range. The decreasing slope of the Arrhenius representation provides an $E_{a} / R$ ratio, whereas its intersection with the $\mathrm{Y}$-axis indicates the value of $\mathrm{D}_{0}$. 


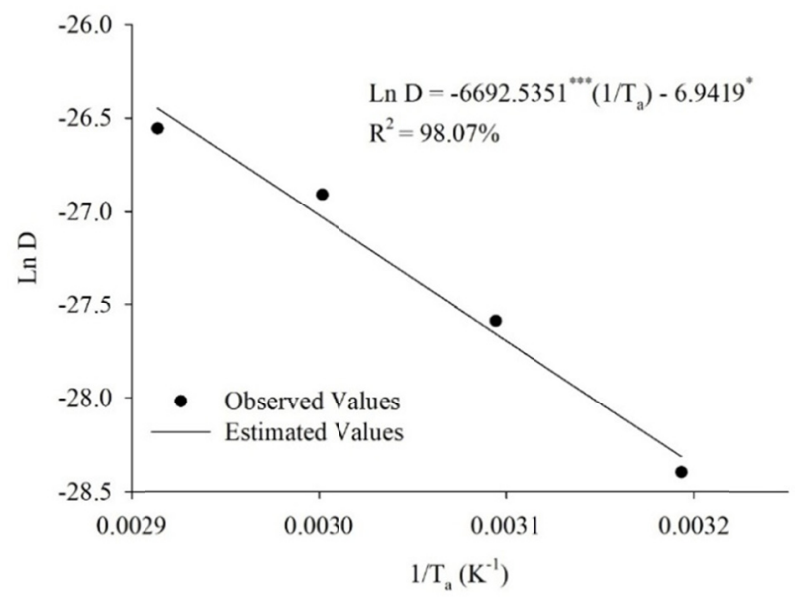

Figure 3. Arrhenius representation of the effective diffusion coefficient for the drying of Piper aduncum leaves under different conditions of temperature

Note. ${ }^{* * *}$ Significant at $0.01 ;{ }^{*}$ Significant at 0.1 by t-test.

The activation energy for water diffusion during the drying kinetics of Piper aduncum leaves was $55.64 \mathrm{~kJ} \mathrm{~mol}^{-1}$. This parameter has been studied by several researchers for various leaves of medicinal plants such as: Bauhinia forficata leaves, $52.95 \mathrm{~kJ} \mathrm{~mol}^{-1}$ (Silva et al., 2017); Serjania marginata leaves, $81.39 \mathrm{~kJ} \mathrm{~mol}^{-1}$ (Martins et al., 2015); Schinus terebinthifolius leaves, $74.96 \mathrm{~kJ} \mathrm{~mol}^{-1}$ (Goneli et al., 2014); Cymbopogon citratus leaves, 63.47 $\mathrm{kJ} \mathrm{mol}^{-1}$ (Martinazzo et al., 2007); Lippia alba leaves, $31.79 \mathrm{~kJ} \mathrm{~mol}^{-1}$ (Barbosa et al., 2007); mint leaves, 62.96 $\mathrm{kJ} \mathrm{mol}^{-1}$ (Doymaz, 2006). The higher the activation energy of the product, the larger the amount of energy required to start the process of molecular liquid diffusion. Determining these experimental values becomes an important information for correct dimensioning of equipment intended for post-harvest of plant products, especially for drying, as well as calculating the energy required for the process to occur efficiently.

According to Martins et al. (2015), the different values of activation energy for different agricultural products can be attributed to their physical and biological characteristics. For Zogzas, Maroulis, and Marinos-Kouris (1996), the values of activation energy for agricultural products vary from 12.7 to $110 \mathrm{~kJ} \mathrm{~mol}^{-1}$. Therefore, the activation energy calculated for Piper aduncum leaves in the present study is within the variation range established by these authors.

In Table 5, it is possible to see that the values of specific enthalpy (h) decrease with increasing temperatures. Lower values of enthalpy indicate less energy required to remove water bound to the product during the drying kinetics, when there is interaction between water molecules and the constituents of the product. This behavior is associated with the effective diffusion coefficient (Figure 2). According to Goneli, Corrêa, Oliveira, and Botelho (2010), the energy required to remove water from the products, which occurs through diffusion in the drying process, is composed of the enthalpy of vaporization of free water and enthalpy of vaporization of water in the product.

Table 5. Thermodynamic properties of the thin-layer drying kinetics of Piper aduncum leaves under different conditions of temperature

\begin{tabular}{lllll}
\hline \multirow{2}{*}{ Thermodynamic properties } & \multicolumn{4}{c}{ Temperature $\left({ }^{\circ} \mathrm{C}\right)$} \\
\cline { 2 - 5 } & 40 & 50 & 60 & 70 \\
\hline$\Delta \mathrm{h}\left(\mathrm{kJ} \mathrm{mol}^{-1}\right)$ & 53.0381 & 52.9549 & 52.8718 & 52.7887 \\
$\Delta \mathrm{s}\left(\mathrm{kJ} \mathrm{mol}^{-1} \mathrm{~K}^{-1}\right)$ & -0.3030 & -0.3032 & -0.3035 & -0.3037 \\
$\Delta \mathrm{G}\left(\mathrm{kJ} \mathrm{mol}^{-1}\right)$ & 147.9350 & 150.9666 & 154.0008 & 157.0375 \\
\hline
\end{tabular}

The specific entropy $(\Delta s)$ (Table 5) has similar behavior to that of enthalpy, i.e., it decreased with increasing drying air temperatures. The lower the temperature, the lower the excitation of water molecules, and it results in an increase in the order of the water-product system (Corrêa et al., 2010). 
According to Nkolo Meze'e, Noah Ngamveng, and Bardet (2008), in order for the sorption sites in agricultural products to be available, Gibbs free energy $(G)$ needs to be attributed since it is able to measure the capacity of a system to perform work. Due to the positive values, it can be understood that the drying kinetics of Piper aduncum leaves does not occur spontaneously. Thus, it is necessary to insert external energy to the product for the process to occur. In this case, the heated air is understood as the external energy.

\section{Conclusions}

Midilli and Valcam models are adequate to represent the drying kinetics of Piper aduncum leaves at temperatures of 60 and $70{ }^{\circ} \mathrm{C}$ and of 40 and $50{ }^{\circ} \mathrm{C}$, respectively.

The effective diffusion coefficient increases with the elevation of air temperature in the drying of Piper aduncum leaves.

The relationship between the effective diffusion coefficient and drying air temperature can be described by the Arrhenius equation, which has an activation energy for the diffusion of Piper aduncum leaves of $55.64 \mathrm{~kJ} \mathrm{~mol}^{-1}$.

The increment in drying air temperature promotes reduction in the values of specific enthalpy and entropy, whereas the values of Gibbs free energy showed the opposite behavior.

\section{Acknowledgements}

The authors extend thanks to PROPP/UFGD, CAPES, CNPq and FUNDECT for their financial support, which was indispensable to the execution of this study.

\section{References}

Al-Ali, M., \& Parthasarathy, R. (2019). Modeling and kinetics study of novel microwave irradiation drying of naproxen sodium drug. Powder Technology, 345(1), 766-774. https://doi.org/10.1016/j.powtec. 2019.01.046

ASABE (American Society of Agricultural and Biological Engineers). (2010). Moisture Measurement-Forages: Standard S358.2 DEC1988, R2008. American Society of Agricultural and Biological Engineers. Standards, Engineering Practices, and Data. St. Joseph: ASABE.

Barbosa, F. F., Melo, E. C., Santos, R. H. S., Rocha, R. P., Martinazzo, A. P., Radünz, L. L., \& Gracia, L. M. N. (2007). Evaluation of mathematical models for prediction of thin-layer drying of Brazilian lemon-scented verbena leaves (Lippia alba (Mill) N.E. Brown). Revista Brasileira de Produtos Agroindustriais, 9(1), 73-82. https://doi.org/10.15871/1517-8595/rbpa.v9n1p73-82

Bastos, C. N., \& Albuquerque, P. S. B. (2004). Efeito do óleo essencial de Piper aduncum no controle em pós-colheita de Colletotrichum musae em banana. Fitopatologia Brasileira, 29(5), 555-557. https://doi.org/ 10.1590/S0100-41582004000500016

Doymaz, I. (2006). Thin-layer drying behavior of mint leaves. Journal of Food Engineering, 74(3), 370-375. https://doi.org/10.1016/j.jfoodeng.2005.03.009

Draper, N. R., \& Smith, H. (1998). Applied regression analysis (3th ed., p. 712). New York: John Wiley \& Sons. https://doi.org/10.1002/9781118625590

Delgado, J. M. P. Q., \& Lima, A. G. B. de. (2016). Drying and Energy Technologies. Springer. https://doi.org/ 10.1007/978-3-319-19767-8

Corrêa, P. C., Oliveira, G. H. H., Botelho, F. M., Goneli, A. L. D., \& Carvalho, F. M. (2010). Modelagem matemática e determinação das propriedades termodinâmicas do café (Coffea arabica L.) durante o processo de secagem. Revista Ceres, 57(5), 595-601. https://doi.org/10.1590/S0034-737X2010000500005

Ferreira Junior, W. N., Resende, O., Oliveira, D. E. C. de., \& Costa, L. M. (2018). Isotherms and isosteric heat desorption of Hymenaea stigonocarpa Mart. seeds. Journal of Agricultural Science, 10(10), 504-512. https://doi.org/10.5539/jas.v10n10p504

Gasparin, P. P., Christ, D., \& Coelho, S. R. M. (2017). Secagem de folhas Mentha piperita em leito fixo utilizando diferentes temperaturas e velocidades de ar. Revista Ciência Agronômica, 48(2), 242-250. https://doi.org/10.5935/1806-6690.20170028

Gomes, F. P., Resende, O., Sousa, E. P., Oliveira, D. E. C. de, \& Araújo Neto, F. R. D. (2018). Drying kinetics of crushed mass of 'jambu': Effective diffusivity and activation energy. Revista Brasileira de Engenharia Agrícola e Ambiental, 22(7), 499-505. https://doi.org/10.1590/1807-1929/agriambi.v22n7p499-505 
Goneli, A. L. D., Corrêa, P. C., Oliveira, G. H. H., \& Botelho, F. M. (2010). Water desorption and thermodynamic properties of okra seeds. Transactions of the ASAE, 53(1), 191-197. https://doi.org/ $10.13031 / 2013.29486$

Goneli, A. L. D., Vieira, M. D. C., Vilhasanti, H. D. C. B., \& Gonçalves, A. A. (2014). Modelagem matemática e difusividade efetiva de folhas de aroeira durante a secagem. Pesquisa Agropecuária Tropical, 44(1), 56-64. https://doi.org/10.1590/S1983-40632014000100005

Guerrini, A., Sacchetti, G., Rossi, D., Paganetto, G., Muzzoli, M., Andreotti, E., ... Bruni, R. (2009). Bioactivities of Piper aduncum L. and Piper obliquum Ruiz e Pavon (Piperaceae) essential oils from eastern ecuador. Environmental Toxicology and Pharmacology, 27(1), 39-48. https://doi.org/10.1016/j.etap.2008.08.002

Haghi, A. K., \& Amanifard, N. (2008). Analysis of heat and mass transfer during microwave drying of food products. Brazilian Journal of Chemical Engineering, 25(3), 491-501. https://doi.org/10.1590/S010466322008000300007

Henderson, S. M. (1974). Progress in developing the thin layer drying equation. Transactions of the ASAE, 17(6), 1167-1172. https://doi.org/10.13031/2013.37052

Henderson, S. M., \& Pabis, S. (1961). Grain drying theory: Temperature effect on drying coefficient. Journal of Agricultural Engineering Research, 6(3), 169-174.

Jideani, V. A., \& Mpotokwana, S. M. (2009). Modeling of water absorption of botswana Bambara varieties using Peleg's equation. Journal of Food Engineering, 92(2), 182-188. https://doi.org/10.1016/j.jfoodeng. 2008.10.040

Karathanos, V. T. (1999). Determination of water content of dried fruits by drying kinetics. Journal of Food Engineering, 39(4), 337-344, 1999. https://doi.org/10.1016/S0260-8774(98)00132-0

Kashaninejad, M., Mortazavi, A., Safekordi, A., \& Tabil, L. G. (2007). Thin-layer drying characteristics and modeling of pistachio nuts. Journal of Food Engineering, 78(1), 98-108. https://doi.org/10.1016/ j.jfoodeng.2005.09.007

Kassem, A. S. (1998). Comparative studies on thin layer drying models for wheat (13th ed.). International Congress on Agricultural Engineering, Morocco.

Maia, J. G. S., Zohhbi, M. G. B., Andrade, E. H. A., Santos, A. S., Silva, M. H. L., Luz, A. I. R., ... Silva, M. H. L. (1998). Constituents of the essential oil of Piper aduncum L. growing wild in the Amazon region. Flavour and Fragrance Journal, 13(4), 269-272. https://doi.org/10.1002/(SICI)1099-1026(1998070)13:4\% 3C269::AID-FFJ744\%3E3.0.CO;2-A

Martinazzo, A, P., Corrêa, P, C., Resende, O., \& Melo, E, C. (2007). Análise e descrição matemática da cinética de secagem de folhas de capim-limão. Engenharia Agrícola e Ambiental, 11(3), 301-306. https://doi.org/ $10.1590 / \mathrm{S} 1415-43662007000300009$

Martins, E. A., Lage, E. Z., Goneli, A. L., Cesar Filho, P. H., \& Lopes, J. G. (2015). Cinética de secagem de folhas de timbó (Serjania marginata Casar). Revista Brasileira de Engenharia Agricola e Ambiental-Agriambi, 19(3), 238-244.

Midilli, A., Kucuk, H., \& Yapar, Z. A. (2002). A new model for single-layer drying. Drying Technology, 20(7), 1503-1513. https://doi.org/10.1081/DRT-120005864

Mohapatra, D., \& Rao, P. S. (2005). A thin layer drying model of parboiled wheat. Journal of Food Engineering, 66(4), 513-518. https://doi.org/10.1016/j.jfoodeng.2004.04.023

Monzote, L., Scull, R., Cos, P., \& Setzer, W. (2017). Essential oil from Piper aduncum: Chemical analysis, antimicrobial assessment, and literature review. Medicines, 4(3), 1-14. https://doi.org/10.3390/medicines 4030049

Nadi, F. (2016). Development of a new model for mass transfer kinetics of petals of Echium amoenum fisch. \& C.A. Mey. under fluidized bed conditions. Food Technology and Biotechnology, 54(2), 217-227. https://doi.org/10.17113/ftb.54.02.16.4304

Lewis, W. K. (1921). The rate of drying of solid materials. Industrial \& Engineering Chemistry, 13(5), 427-432. https://doi.org/10.1021/ie50137a021 
Nkolo Meze'e, Y. N., Noah Ngamveng, J., \& Bardet, S. (2008). Effect of enthalpy-entropy compensation during sorption of water vapour in tropical woods: The case of Bubinga (Guibourtia Tessmanii J. Pellegriniana J. L.). Thermochimica Acta, 468(1-2), 1-5. https://doi.org/10.1016/j.tca.2007.11.002

Page, G. E. (1949). Factors influencing the maximum rates of air drying shelled corn in thin layers. West Lafayette: Purdue University.

Quequeto, W. D., Siqueira, V. C., Ferranti, L. F., Schoeninger, V., \& Leite, R. A. (2017). Cinética de secagem dos grãos de feijão cultivar IPR Tangará. Revista Energia na Agricultura, 32(4), 408-415. https://doi.org/ 10.17224/EnergAgric.2017v32n4p408-415

Reis, R. C. dos, Devilla, I. A., Ascheri, D. P., Servulo, A. C., \& Souza, A. (2012). Cinética de secagem de folhas de manjericão (Ocimum basilicum L.) via infravermelho. Revista Brasileira de Engenharia Agricola $e$ Ambiental-Agriambi, 16(12), 1346-1352. https://doi.org/10.1590/S1415-43662012001200012

Siqueira, V. C., Resende, O., \& Chaves, T. H. (2013). Mathematical modelling of the drying of jatropha fruit: An empirical comparison. Revista Ciência Agronômica, 44(2), 278-285. https://doi.org/10.1590/ S1806-66902013000200009

Siqueira, V. C., Borém, F. M., Alves, G. E., Isquierdo, E. P., Pinto, A. C. F., Ribeiro, D. E., \& Ribeiro, F. C. (2017). Drying kinetics of processed natural coffee with high moisture content. Coffee Science, 12(3), 400-409. https://doi.org/10.25186/cs.v12i3.1320

Silva, F. P. D., Siqueira, V. C., Martins, E. A., Miranda, F., \& Melo, R. M. (2017). Thermodynamic properties and drying kinetics of Bauhinia forficata Link leaves. Revista Brasileira de Engenharia Agrícola $e$ Ambiental, 21(1), 61-67. https://doi.org/10.1590/1807-1929/agriambi.v21n1p61-67

Sousa, F. C., Martins, J. J. A., Rocha, A. P. T., Gomes, J. P., Pessoa, T., \& Martins, J. N. (2015). Predição de modelos sobre a cinética de secagem de folhas de Ziziphus joazeiro Mart. Revista Brasileira de Plantas Medicinais, 17(2), 195-200. https://doi.org/10.1590/1983-084X/12_071

Sharaf-Eldeen, Y. I., Blaisdell, J. L., \& Hamdy, M. Y. (1980). A model for ear corn drying. Transactions of the ASAE, 23(1), 1261-1265. https://doi.org/10.13031/2013.34757

Thompson, T. L., Peart, R. M., \& Foster, G. H. (1968). Matllematical simulation of corn drying a new model. Transaction of the ASAE, 11(4), 582-586. https://doi.org/10.13031/2013.39473

Villamizar, L. H., Cardoso, M. D. G., Andrade, J. D., Teixeira, M. L., \& Soares, M. J. (2017). Linalool, a Piper aduncum essential oil component, has selective activity against Trypanosoma cruzi trypomastigote forms at $4{ }^{\circ} \mathrm{C}$. Memórias do Instituto Oswaldo Cruz, 112(2), 131-139. https://doi.org/10.1590/0074-02760160361

Verma, L. R., Bucklin, R. A., Endan, J. B., \& Wratten, F. T. (1985). Effects of drying air parameters on rice drying models. Transactions of the ASAE, 28(1), 296-301. https://doi.org/10.13031/2013.32245

Wang, J., Law, C. L., Nema, P. K., Zhao, J. H., Liu, Z. L., Deng, L. Z., ... Xiao, H. W. (2018). Pulsed vacuum drying enhances drying kinetics and quality of lemon slices. Journal of Food Engineering, 224, 129-138. https://doi.org/10.1016/j.jfoodeng.2018.01.002

Wang, C. Y., Singh, R. P. (1978). Use of variable equilibrium moisture content in modeling rice drying. Transaction of the ASAE, 11(1), 668-672.

Wolfinger, R. D. (1993). Covariance structure selection in general mixed models. Communications in Statistics, 22(4), 1079-1106. https://doi.org/10.1080/0361091930 8813143

Xavier, W. D., Silva, D. D. A., Resende, O., Guimarães, C. M., Bastos, A. V. S., \& Ferreira Junior, W. N. (2019). Drying kinetics of chives (Allium fistulosum L.). Journal of Experimental Agriculture International, 29(1), 1-10. https://doi.org/10.9734/JEAI/2019/45463

Yilbas, B. S., Hussain, M. M., 7 Dincer, I. (2003). Heat and moisture diffusion in slab products to convective boundary condition. Heat Mass Transf, 39, 471-476. https://doi.org/10.1007/s00231-002-0323-X

Yagcioglu, A., Degirmencioglu, A., \& Cagatay, F. (1999). Drying characteristics of laurel leaves under different conditions. International Congress on Agricultural Mechanization and Energy, Cukurova University, Adana.

Zogzas, N. P., Maroulis, Z. B., \& Marinos-Kouris, D. (1996). Moisture diffusivity data compilation in foodstuffs. Drying Technology, 14, 2225-2253. https://doi.org/10.1080/07373939608917205 


\section{Copyrights}

Copyright for this article is retained by the author(s), with first publication rights granted to the journal.

This is an open-access article distributed under the terms and conditions of the Creative Commons Attribution license (http://creativecommons.org/licenses/by/4.0/). 